\title{
BRIEF CRITICAL ANALYSIS OF CONCEPTS USED FOR ASSESSING THE MARKET VALUE OF ECOSYSTEM GOODS AND SERVICES IN URBAN AND SPATIAL PLANS
}

\author{
Petrişor Alexandru-Ionut \\ "Ion Mincu" University of Architecture and Urban Planning \& National \\ Institute for Research-Development in Constructions, Urban Planning and \\ Sustainable Spatial Development URBAN-INCERC, Bucharest (ROMANIA)
}

\begin{abstract}
Estimating the market value of natural capital is largely influenced by the perception of the environment. Anthropocentric approaches, particularly the sectoral ones still used today by non-specialists tributary to conceptions lasting since the 1950 's, made economists see the environment as an endless resource for human development. This reasoning - "only money matters" - led to the ecological crisis. Its first solution, the 'zero growth' concept of the Club of Rome, based on the same model, proved unviable. Later the sustainability concept embedded the progress of systemic ecology, including the shift of its object to coupled socio-ecological complexes. Paradigm changes modified the interpretation of ecological balance, and implicitly the perception of the relation between socio-economic development and biodiversity conservation, analyzed finally through the carrying capacity. The dynamic of this theoretical framework changed the methods used to find the market value of environmental goods and services, moving from the money approach (economic) to the carbon footprint (environmental) and then to ecosystem services provided by the ecological infrastructure (holistic). Sustainability must rely on seeing the environment as hierarchy of coupled socioecological systems, and, in practice, impact assessment must look at the effects of human actions on structural integrity and level of ecosystem services provided by the ecological infrastructure.
\end{abstract}

Keywords: holistic approach, carrying capacity, ecological infrastructure, ecosystem services

\section{PERCEPTION OF THE ENVIRONMENT: ECOLOGICAL AND ECONOMIC APPROACHES}

The concept of environment was perceived, across the evolution of environmental sciences, based on two approaches; the anthropocentric model was replaced by systemic ecology with a holistic one [40]. In the first case, the accent is set on 
humans (individuals or society), and the environment is simply a surrounding envelope - "surrounding nature including things and beings" [14], endless provider of resources and absorber of waste. Species are useful or damaging according to the human interest directed to the domination of nature. This approach resulted into an uncontrolled development, with negative impacts against the environment. A particular anthropocentric approach is the sectoral one; the environment consists of "environmental factors" - water, air, soil, flora and fauna: "all factors, natural or created by human activities, providing through their interaction for the maintenance of ecological balance and determining the living conditions of humans and development of society' [13]. Anthropocentric approaches rely on several implicit erroneous perceptions: the stock of resources is endless; when the resources are gone, we will move; the higher the welfare, the better is our life; the cots of projects depends on the costs of matter, energy and work - only economy matters; nature must be dominated; new laws and technologies will solve the environmental crisis; we are superior to the nature and isolated from it; and the generation of waste through each activity is simply normal [42].

The opposite approach is the holistic one, provided by systemic ecology. The environment is a hierarchy of organized ecological systems, including the natural and man-dominated ones. However, the object of ecology shifted from organisms [24] to ecosystems [57], complexes of ecosystems [63] and finally coupled socioecological complexes [67]. The 1992 United Nations Conference on the Environment and Development acknowledged that human society is part of the environment, ethno-cultural diversity is a component of biodiversity, and environmental quality is a key element of life quality. BSRIA ("The Building Services Research and Information Association") proposed an economic approach based on the existence of four types of capital: natural - granting a market value to environmental goods and services, including the non-productive ones, such as biodiversity, beauty of landscape or ecological corridors; man-generated buildings, machinery and infrastructure; human - practical knowledge and abilities of the population; and social - legislative and economic relationships ensuring the cohesion and stability of society [9]. Generally, authors distinguish: the natural capital - network of natural systems and anthropized systems resulted from the simplification and transformation of the first ([63], p. 100), consisting of goods and services [35], created capital - physical capital, produced by humans [9], social or institutional capital, and human or cultural capital ([63], p. 132). In the same context, authors identify a world natural and cultural heritage, and sustainability policies address the two components together. According to the 1972 Paris World Heritage Convention, this heritage includes all monuments, produced by man or natural. The Ouagadougou Francophone Summit (Burkina Faso, 2004) added a cultural dimension, as cultural diversity is an economic growth factor [29]. Its recognition in 2010 is the result of an intense lobby from the United Cities and Local Governments [61]. On a similar note, the 2007 Leipzig Charter of Sustainable European Cities uses the term 'Baukultur' as a sum of cultural, economic, technological, social and ecological factors influencing the urban planning [62].

\section{APPROACHES OF THE RELATIONSHIP BETWEEN SOCIO- ECONOMIC DEVELOPMENT AND THE ENVIRONMENT}

The dynamic of the relationship between socio-economic and natural systems is represented in Table 1. The pressures against natural systems result in impacts, united under the term 'environmental deterioration': over-exploitation of resources, 
pollution, loss of biodiversity, introduction of alien species, fragmentation of habitats, genetic modification, large works on waters etc. ([41], [42]), signaled first by Rachel Carson's Silent Spring [11] and then by the 1970' oil crisis [42].

Table 1. A timeline of the relationships between human society and natural systems.

\begin{tabular}{|l|l|l|l|l|}
\hline \multicolumn{1}{|c|}{ Moment } & Early history & \multicolumn{1}{|c|}{$\begin{array}{c}\text { Industrial } \\
\text { revolution }\end{array}$} & $\begin{array}{c}\text { Oil Crisis, Club of } \\
\text { Rome (1970's) }\end{array}$ & $\begin{array}{c}\text { Brundtand Report (1988); } \\
\text { UNCED (1992) - present }\end{array}$ \\
\hline Model & No model & No model & "Zero growth" strategy & Sustainable development \\
\hline Action & $\begin{array}{l}\text { Life in } \\
\text { harmony } \\
\text { with nature }\end{array}$ & $\begin{array}{l}\text { Deterioration of } \\
\text { the natural capital }\end{array}$ & $\begin{array}{l}\text { Strict conservation } \\
\text { (preservation) of } \\
\text { biodiversity }\end{array}$ & $\begin{array}{l}\text { Conservation, impact } \\
\text { assessment, restoration, } \\
\text { internalization of externalities }\end{array}$ \\
\hline $\begin{array}{l}\text { Ecological } \\
\text { approach }\end{array}$ & None & Anthropocentric & Anthropocentric & Holistic \\
stop impaction of goods & $\begin{array}{l}\text { Development would } \\
\text { stop-development of natural } \\
\text { systems and human society }\end{array}$ \\
\hline
\end{tabular}

The first answer to the crisis belongs to the Club of Rome, which proposed the 'zero growth strategy' stopping both development and its impacts [33]. Since the solution was not viable, searches continued, focusing on a change of conscience and ethics ([31], p. 176), technological solutions [53], a new view of megalopolises [15], or economic, social or political issues ([42], [46]). Synthesizing all these, the 1987 concept of 'sustainability' aimed for a development meeting current and future needs at the same rate [8]. The concept has a spatial dimension and relies on three traditional pillars (economic, social, environmental) and a newer cultural one [51]. Adding the practical actions implied, sustainability can be defined as "use of natural resources within the carrying capacity limits, conservation of biodiversity, ecological restoration of degraded systems and environmental protection measures integrated in sectoral development strategies aimed at internalizing environmental costs by assessing the anthropogenic impact" [44].

The dynamic of development can be analyzed using the four types of capital defined above - natural, created, human and social ([9], [16]). Historically, in the classic economy the environment was perceived as an endless resource and the created capital was grown at the expense of the natural one (ecological crisis). The 'zero growth model' determines the stagnation of the two, while ecological economics can only decelerate the decrease of the two. Only sustainability, if ecological restoration is included, results into their growth ([68][69]).

Last but not least, the energy-based approach offers an important perspective on development, especially because the two concepts involved (primary eco-energy and urbanization) are operational at different spatial scales [28], and tied to the economic approach. Primary energy is the initial energy of a system before the conscious intervention of man against its structure [26]. During the anthropization (and, later, urbanization), the concentration of population and economic activities results into different consumption rates of resources or primary eco-energies [26], which can be measured using the level of degradation. The level of anthropization is inversely proportional to primary eco-energies and responsible for the increased geo-complexity. Professor A. Vădineanu shows that anthropization simplifies and fragments natural systems, reducing their biodiversity ([63], pp. 133-134). Socioeconomic systems tend to couple to the natural ones through all functions: energy is taken directly (humans are top consumers), or through anthropization; energy and resources are absorbed developing technologies ([56], pp. 9-10), dissipating natural energy and introducing it in amounts exceeding the contribution of primary producers ([42]); the increased complexity of absorption channels reflects the 
structuring character of human activities against the geographic space ([56], p. 9); the alteration of biogeochemical cycles and loss of biodiversity decrease the stability of man-dominated systems, which become dependent on human actions ([48], [52]). At the same time, urbanization determines the emergence of new structures, specific to socio-economic systems [55], increasing the complexity of territorial systems ([26], p. 54), and geo-diversity. If natural resources are managed respecting the environment [27], based on a holistic model [66], biodiversity is increased by work [64], and finally geo-diversity increases [52]. Therefore, urbanization increases geo-diversity, but decreases biodiversity; the phenomenon is illustrated by the dynamic of the two types of capital - the declining natural one reflects biodiversity, and the increasing created capital of socio-economic systems corresponds to geo-diversity [52].

\section{CONSERVATION, DEVELOPMENT, ECOLOGICAL BALANCE, CARRYING CAPACITY}

The stability of ecological systems can be interpreted based on the following measures: resilience - speed of return to equilibrium after the action of a stressor; persistence - steadiness to the pressure of stressors, measured by the duration of equilibrium; resistance - range of fluctuations under the action of stressors; and variability - frequency of changes under the action of stressors [63]. The interpretation of stability depends on understanding equilibrium as a dynamic one, with numerous equilibrium basins and attractors. While mechanical systems have a predictable dynamic, characterized by static equilibrium, presuming an unique state to which the system returns after the action of stressors, natural systems are in dynamic equilibrium, a succession of disequilibrium and relative equilibrium states, and differentiated dynamics ([26], p. 38). In this case, the stability domain is described by the carrying capacity ([63], pp. 94-100; [6], pp. 18-19). The dynamic is oriented by adaptive cycles, determined by the relation with integrated and integrated systems and other systems of the same rank ([23], [25], [65]).

Based on the energy consumption, ecological systems have an anti-entropic behavior. More exactly, they increase the inner complexity (diversity) and the system becomes more stable, meaning a certain periodicity of fluctuations in its variables [40]. Initially ecologists assumed a linear model, but later on it was found out that there is an optimum diversity corresponding to maximum stability when species are associated through stable relationships [59], and the diversity deficit or excess destabilizes the system, repositioning it on a new evolution trajectory [40]. Conservation is defined as "maintenance or restoration of natural habitats and wild populations to a favorable state" [21], related to the long-term maintenance of self-regulation ability or carrying capacity - "ability to provide, under equilibrium conditions, resources for a well defined human population, absorbing its positive impact and eliminating the negative ones" [70]. There is a difference between the strict preservation in the 'zero growth' model, assuming the utopian maintenance in an intact state, and the sustainability interpretation, where human activities can continue as long as they do not affect the carrying capacity [47].

\section{INTERNALIZING EXTERNALITIES - THE PRACTICE}

One of the components of sustainability is the impact assessment, aimed at finding the adverse outcomes of activities, projects or actions [40]. The procedure applies the 'polluter pays' low principle, as the costs implied by alleviating effects are 
internalized to those who generated them instead of becoming externalities supported by others. Based on the law system, internalization is punitive (fines) or cooperative, accounting also for increasing ecological awareness (permits, negotiable quotas, stimulating incentives); the last type of solutions encourage the change of projects including solutions for diminishing their environmental impact.

\subsection{Money approach - finding the market value of the environment}

The market value of environmental goods and services cannot be determined directly and is often underestimated, as they are not always known, their market value is not known, or there is no market [40]. However, it can be estimated based on few methods ([5], [22], [70]): (1) substitution, based on (a) protection costs prevention is preferred until costs equal the availability to pay for reducing health risks; (b) hedonist prices - regression used to analyze prices based on visible attributes; (c) travel cost - better environmental quality attracts tourists; the value is determined in money and time; (2) hypothetic markets - questionnaires asking people how much would pay to avoid costs or obtain benefits; (3) indirectly, using correlations to look at the dose-response or dose-effect relationships.

\subsection{Ecological (carbon) footprint}

R. Ambroise (French Ministry of Agriculture) discusses the effect of sectorality each need is now satisfied by different land parcels; soon their summed area will exceed the Earth surface [42]. In this regard, the ecological footprint is used to look at the anthropogenic impact [43]; it measures the pressure against natural systems by estimating the terrestrial or sea area capable of biological productivity which needs to be regenerated due to the resource consumption and generation of waste by the human population, provided the current technological and knowledge development [12]. In simpler words, it measures the natural area needed to support a human population with the same lifestyle [3] in three ways: vegetated area able to absorb the $\mathrm{CO}_{2}$ resulted from burning fossil fuels, not absorbed by the ocean; cultured area able to produce an amount of ethanol equivalent to the fuels; vegetated area needed in the geological past to generate the fossil fuels [12].

\subsection{Ecosystem services}

Although brought to the agenda relatively recently by the Millennium Ecosystem Assessment, the concept of ecosystem services is not new. In the economic approach, the natural capital is the infrastructure generating goods and services for the human society. The concept of ecosystem services includes goods as a service (provision of goods). It is very possible that this approach is the result of conservationist lobby, alarmed by the fact that ecological restoration and conservation focused on goods, which were easier to quantify, more familiar to economists, and, unlike services, had also a market. Ecosystem services are benefits obtained by the human society from ecosystems [74] or capacity of robust ecosystems to provide, directly or indirectly, services essential to the healthy functioning of human society [73]. They are classified as provision (food, water); (2) regulation (floods, hazards); cultural (spiritual, recreation); and support (nutrient cycling) ([71], [74]). This perspective is also functional, as a normally working system has biological productivity, yielding goods and services to the human society [27]. The normal operation and level of services depend on biodiversity [36]. These services have economic, social, cultural, insurance [19], 
biophysical, health and justice value [20], can reduce overall pollution and mitigate climate changes [30], allowing for reconciling cities and people with nature [20].

\subsection{Ecological infrastructure}

Urban ecology had, across its evolution, three directions of research: ecology in cities (particularities of the urban system), ecology of cities (study of socioecological complex), and sustainability of cities [72]. From the ecology standpoint, cities are incomplete and immature systems; their diversity is reduced to species tolerated and controlled by humans - hemerophile or synanthrope, ubiquitous or opportunistic, and random ([37], [37], [42], [45], [49]). Humans favor alien (often invasive) species and domestic ones; most of them are found in the green spaces. In general, there are four types of city nature: remains of natural systems (forests reduced to parks); expansion of natural systems (agricultural, forests); landscaped areas (parks, green spaces); spontaneous, invasive or ruderal species ([7], [54]).

The green or ecological infrastructure is a strategically planned network consisting of quality natural and semi-natural areas and other environmental components, designed and managed to provide ecosystem services and conserve urban and rural biodiversity [17], or network of open spaces, forested areas, wild habitats, parks and other natural areas cleaning air and water, providing natural resources and enhancing urban life quality [32]. It consists of ecological corridors (trees, green spaces, water courses, bicycle or pedestrian tracks, urban areas (boulevards, squares, green roofs and facades), industrial parks, suburban areas (relaxation, social interaction, events, agriculture), (5) sustainable draining systems (pools, grass-covered canals, wetlands) and coastal areas ([2], [4], [18], [60]). Ecological corridors connect different habitats penetrating the urban tissue [1].

The concept of green infrastructure is operational and useful for planners and daily practice [34]; studies carried out in Romania found out that the green infrastructure corresponds to the types of city nature [50]. Moreover, the green infrastructure provides ecological services ([32], [39], [58]) such as flood control or water supply [32], reduces the effects of climate changes ([18], [34]), conserves biodiversity [60] and ensures the normal functioning of ecosystems ([10], [60]) and human health [10].

\section{CONCLUSIONS}

The correlated dynamics of theoretical and practical foundations shows that the premises of sustainability cannot be ensured unless the environment is seen as a hierarchy of coupled socio-ecological complexes. The dissociation of humans is incompatible with a long term development balancing economic, social, cultural and environmental needs. From this perspective, human actions must not affect the carrying capacity of the ecological foundation represented of the natural systems supporting life. In order to reach this goal, impact assessment must not be a set of sectoral analyses of "environmental factors", but an integrated assessment of the ecological infrastructure, looking at its structural integrity and evaluating correctly and completely the ecosystem services provided by it. 


\section{REFERENCES}

[1] Angold, P. G., Sadler, J. P., Hill, M. O., Pullin, A., Rushton, S., Austin, K., Small, E., Wood, B., Wadsworth, R., Sanderson, R., Thompson, K. (2006), "Biodiversity in urban habitat patches", Science of the Total Environment, 360, 196-204.

[2] ASOP Romania (2014), Ecological Infrastructures Categories (in Romanian), paper presented at Public Space \#2. [Eco]logical Infrastructure Conference, Timişoara, Romania.

[3] BBC News (2007), "Global ecosystems 'face collapse', http://news.bbc.co.uk/2/hi/science/nature/6077798.stm (accessed May 1, 2007)

[4] Benedict, M. A., McMahon, E. T. (2002), "Green Infrastructure: Smart Conservation for the 21st Century", Renewable Resources Journal 20, 3, 12-17.

[5] Biodiversity Office of Moldova (2005), Developing mechanisms and means for stimulating the practices of sustainable use of renewable natural resources in the economic and social conditions of transition specific to Moldova, Report of the project "Evaluation of needs for developing the operational capacity in biodiversity conservation and identification of national priorities" (in Romanian), Chişinău, Moldova.

[6] Botnariuc, N. (1999), Evolution of supra-individual biological systems (in Romanian), Bucahrest University Press, Bucharest, Romania.

[7] Breuste, J., Qureshi, S., Li, J. (2013), "Scaling down the ecosystem services at local level for urban parks of three megacities", Hercynia N. F., 46, 1-20.

[8] Brundtland, G. H. (1987), Our Common Future, Oxford University Press, Oxford, UK.

[9] Building Services Research and Information Association - BSRIA (1996), "Sustainable construction - the UK viewpoint", Report 79150/1 Draft 2 for consultation, Building Services Research and Information Association, London, UK.

[10]Cameron, R. W. F., Blanuša, T., Taylor, J. E., Salisbury, A., Halstead, A. J., Henricot, B., Thompson, K. (2012), "The domestic garden - Its contribution to urban green infrastructure", Urban Forestry \& Urban Greening, 11, 2, 129-137.

[11]Carson, R. (1962), Silent Spring, Houghton Mifflin, Boston, US.

[12]Chambers, N., Simmons, C., Wackernagel, M. (2000), "Sharing Nature's Interest: Ecological Footprints as an Indicator of Sustainability", Earthscan, London, UK.

[13]Chioreanu, A., Mâciu, M., Nicolescu, N. C., Rădulescu, G., Şuteu, V. (1978), Brief Encyclopedic Dictionary (in Romanian), Scientific and Encyclopedic Press, Bucharest, Romania.

[14] Coteanu, I., Seche, L., Seche, M. (1975), Brief explanatory dictionary of the Romanian language (in Romanian), Romanian Academy Press, Bucharest, Romania.

[15] Dansereau, P., Weadock, V. A. (1970), Challenge for Survival: Land, Air, and Water for Man in Megalopolis, Columbia University Press, New York, NY, US.

[16]Dwyer, C. A., Gallagher, A., Levin, J., Morley, M. E. (2003), "What is Quantitative Reasoning? Defining the Construct for Assessment Purposes", Research Report, Educational Testing Service, Princeton, NJ, US.

[17] European Comission (2013), "Building a Green Infrastructure for Europe", Publications Office of the European Union, Luxemburg, Luxemburg.

[18] Gill, S. E., Handley, J. F., Ennos, A. R., Pauleit, S. (2007), "Adapting Cities for Climate Change: The Role of the Green Infrastructure", Built Environment, 33, 1, 115-133.

[19] Gómez-Baggethun, E., Barton, D. N. (2013), "Classifying and valuing ecosystem services for urban planning", Ecological Economics, 86, 235-245.

[20] Gómez-Baggethun, E., Gren, Å., Barton, D. N., Langemeyer, J., McPhearson, T., O'Farrell, P., Andersson, E., Hamstead, Z., Kremer, P. (2013), "Urban Ecosystem Services", Elmqvist, T., Fragkias, M., Goodness, J., Güneralp, B., Marcotullio, P. J., McDonald, R. I., Parnell, S., Schewenius, M., Sendstad, M., Seto, K. C., Wilkinson C., 
Urbanization, Biodiversity and Ecosystem Services: Challenges and Opportunities. A Global Assessment, Springer, Amsterdam, The Netherlands, 175-251.

[21] Government of Romania (2007), "Emergency Ordinance no. 57 of 2007 on the regime of natural protected areas, conservation of natural habitats and wild flora and fauna" (in Romanian), Official Gazette, 442.

[22] Grădinaru, G., Maniu, I. I., Gheţu, A. (2005), "Producing an integrated indicator system for analyzing the environmental impact of economic activity. Research Report" (in Romanian), Revista de Politica Ştiinţei şi Scientometrie, special issue, 1-53.

[23] Gunderson, L. H., Holling, C. S. (2001), Panarchy: understanding transformations in human and natural systems, Island Press, Washington, DC, US.

[24] Haeckel, E. (1866), General morphology of organisms (in German), Georg Reimer, Berlin, Germany.

[25]Holling, C. S. (2004), "From complex regions to complex worlds", Ecology and Society, 9, 1, 11.

[26] Ianoş, I. (2000), Territorial systems. A geographic approach (in Romanian), Technical Press, Bucharest, Romania.

[27] Ianoş, I., Peptenatu, D., Zamfir, D. (2009), "Respect for environment and sustainable development", Carpathian Journal of Earth and Environmental Sciences, 4, 1, 81-93.

[28]Ianoş, I., Petrişor, A.-I., Stoica, I. V., Sârbu, C. N., Zamfir, D., Cercleux, A. L. (2011),

"The different consuming of primary eco-energies and their degradation in territorial systems", Carpathian Journal of Earth and Environmental Sciences, 6, 2, 251-260.

[29]Iliescu, I. (2005), For sustainable development (in Romanian), Semne, Press, Bucharest, Romania.

[30]La Greca, P., La Rosa, D., Martinico, F., Privitera, R. (2011), "Agricultural and green infrastructures: The role of non-urbanised areas for eco-sustainable planning in a metropolitan region", Environmental Pollution, 159, 2193-2202.

[31] László, E. (2004), Science and the Akashic Field: An Integral Theory of Everything, Inner Traditions, Rochester, Vermont, US.

[32]McMahon, E. T. (2000), "Green Infrastructure", Planning Commissioner Journal, 37, 4-7.

[33]Meadows, D. H, Meadows, D. L, Randers, D. L., Randers, J., Behrens, W. W. III (1972), The limits to growth: A report for the club of Rome's project on the predicament of mankind, Potomac Associates Books, Earth Island, London, UK.

[34]Mell, I. C. (2008), "Green Infrastructure: concepts and planning", Newcastle University Forum Ejournal 8, 69-80.

[35] Negrei C. C. (1999), "Environmental accounting" (in Romanian), Vădineanu, A., Sustainable development, vol. 2, Mechanisms and instruments (in Romanian), Bucharest University Press, Bucharest, Romania, 136-158.

[36] Niemelä, J., Saarela, S.-R., Söderman, T., Kopperoinen, L., Yli-Pelkonen, V., Väre, S., Kotze, D. J. (2010), "Using the ecosystem services approach for better planning and conservation of urban green spaces: a Finland case study", Biodiversity and Conservation, $19,3225-3243$.

[37]Noblet, J.-F. (1994), The nest house. People and beasts: how to live together (in French), Terre vivante, Paris, France.

[38] Noblet, J.-F. (2005), The nature under your roof. People and beasts: how to live together (in French), Delachaux et Niestlé, Paris, France.

[39] Pauleit, S., Ennos, R., Golding, Y. (2005), "Modeling the environmental impacts of urban land use and land cover change - a study in Merseyside, UK", Landscape and Urban Planning 71, 295-310. 
[40] Petrişor, A.-I. (2007), Environmental analyses for urban and landscape planning (in Romanian), Ion Mincu University Press, Bucharest, Romania.

[41] Petrişor, A.-I. (2008), "Ecology and environmentalism" (in Romanian), Amenajarea Teritoriului şi Urbanismul, 7, 1-2, 49-50.

[42] Petrişor, A.-I. (2008), Urban ecology, sustainable spatial development and legislation (in Romanian), România de mâine Press, Bucharest, Romania.

[43] Petrişor, A.-I. (2008), "Levels of biological diversity: a spatial approach to assessment methods", Romanian Review of Regional Studies, 4, 1, 41-62.

[44] Petrişor, A.-I. (2009), "The theory and practice of conserving biodiversity through urban and spatial plans" (in Romanian), Amenajarea Teritoriului şi Urbanismul, 8, 3-4, 1524.

[45] Petrişor, A.-I. (2010), "Urban environment: an ecological approach" (in Romanian), Urbanistique, $\quad$ http://www.urbanistique.ro/mediul-urban-o-abordare-ecologica-dralexandru-ionut-petrisor/\#more-127 (accessed December 2, 2010).

[46] Petrişor, A.-I. (2010), "Man, status of the urban environment and urban development. A summary of theory, models and viewpoints" (in Romanian), Repere, 2, 56-61.

[47] Petrişor, A.-I. (2011), "Spatial principles of preserving biodiversity in natural protected areas" (in Romanian), Analele Arhitecturii, 6, 1, 37-39.

[48] Petrişor, A.-I. (2012), "Comparative critical analysis of systems studied by ecology, geography and spatial planning", Posea, G., Andrei, M. T., Zăvoianu, I., Cruceru, N., Benea, I., Văduva, I., Dumitraşcu, C., Landscapes: Perception, knowledge, awareness, and action. Proceedings of the FG-SHU International Symposium on Geography, Addleton Academic Publishers, New York, 94-108.

[49] Petrişor, A.-I. (2013), "Are human settlements ecological systems?", Oltenia. Studii şi comunicări. Ştiinţele Naturii, 29, 1, 227-232.

[50] Petrişor, A.-I. (2015), "Assessment of the Green Infrastructure of Bucharest using CORINE and Urban Atlas data", Urbanism. Architecture. Constructions, 6, 2, 19-24.

[51] Petrişor, A.-I., Petrişor, L. E. (2014), "25 years of sustainability. A critical analysis", Present Environment and Sustainable Development, 8, 1, 175-190.

[52]Petrişor, A.-I., Sârbu, C. N. (2010), "Dynamics of geodiversity and eco-diversity in territorial systems", Journal of Urban and Regional Analysis, 2, 1, 61-70.

[53]Program for the Human Environment (1996), "The Liberation of the Environment", Daedalus, 125, 3.

[54]Qureshi, S., Breuste, J. H. (2010), "Prospects of Biodiversity in the Mega-City of Karachi, Pakistan: Potentials, Constraints and Implications", Müller, N., Werner, P., Kelcey, J. G., Urban Biodiversity and Design, 1st edition, Blackwell, Chichister, UK, 497-517.

[55]Sârbu, C. N. (1999), "Urban rehabilitation and development - main dimension of socio-economic transition" (in Romanian), Vădineanu, A., Sustainable development, vol. 2, Mechanisms and instruments (in Romanian), Bucharest University Press, Bucharest, Romania, 298-329.

[56]Sârbu, C. N. (2006), Housing in Romania: a framework approach (in Romanian), Ion Mincu University Press, Bucharest, Romania.

[57]Tansley, A. G. (1935), "The use and abuse of vegetational concepts and terms", Ecology, 16, 284-307.

[58] Taylor Lovell, S., Taylor, J. R. (2013), "Supplying urban ecosystem services through multifunctional green infrastructure in the United States", Landscape Ecology, 28, 14471463.

[59]Tomescu, I., Savu, A. D. (2002), "The relationship petween diversity and stability of forest ecosystems" (in Romanian), in Proceedings of University's Day 8th International 
Conference, Târgu Jiu, May 24-26, 2002, Constantin Brâncuşi University - Engineering Faculty, Târgu Jiu, Romania, 1-4.

[60]Tzoulas, K., Korpela, K., Venn, S., Ylipelkonen, V., Kazmierczak, A., Niemela, J., James, P. (2007), "Promoting ecosystem and human health in urban areas using green infrastructure: A literature review", Landscape and Urban Planning, 81, 167-178.

[61] United Cities and Local Governments (2010), "Culture: Fourth Pillar of Sustainable Development. Policy statement", United Cities and Local Governments, Barcelona, Spain.

[62] Urban Observer (2008), "The Leipzig charter for sustainable European cities" (in Romanian), Buletin informativ al Uniunii Arhitecţilor din România, 1, 21.

[63]Vădineanu, A. (1998), Sustainable development, vol. 1. Theoretical foundations of sustainability (in Romanian), Bucharest University Press, Bucharest, Romania.

[64]Vădineanu, A. (2004), "Money: creation and use of incomes" (in Romanian), Vădineanu, A., Management of development. An eco-systemic approach (in Romanian), Ars Docendi Press, Bucharest, Romania, 126-132.

[65]Vădineanu, A. (2004), "Development and sustainability of socio-ecological complexes" (in Romanian), Vădineanu, A., Management of development. An eco-systemic approach (in Romanian), Ars Docendi Press, Bucharest, Romania, 41-51.

[66]Vădineanu, A. (2004), "Adaptive and eco-systemic management of development. Introduction" (in Romanian), Vădineanu, A., Management of development. An ecosystemic approach (in Romanian), Ars Docendi Press, Bucharest, Romania, 73-74.

[67]Vădineanu, A. (2004), "Particularities of the conceptual model" (in Romanian), Vădineanu, A., Management of development. An eco-systemic approach (in Romanian), Ars Docendi Press, Bucharest, Romania, 75-83.

[68]Vădineanu, A. (2006), "Conservation and ecological restoration of lake sytems: requirements, opportunities and limits" (in Romanian), paper presented at the workshop "Longitudinal and lateral connectivity of watercourses", 2007, Romanian Ministry of the Environment and Sustainable Development, Bucharest, Romania.

[69]Vădineanu, A. (2007), "Conservation of bio- and eco-diversity and socio-economic development in Romania" (in Romanian), paper presented at the National Ecology Conference, 12 October 2007, Mamaia, Romania.

[70]Vădineanu, A., Negrei, C., Lisievici, P. (1999), Sustainable development, vol. 2, Mechanisms and instruments (in Romanian), Bucharest University Press, Bucharest, Romania.

[71]Watson, R., Zakri, A. H. (2005), Ecosystems and Human Well-being. Synthesis, Island Press, Washington, DC, US.

[72]Wu, J. (2014), "Urban ecology and sustainability: The state-of-the-science and future directions", Landscape and Urban Planning, 125, 209-221.

[73]Young, R. F. (2010), "Managing municipal green space for ecosystem services", Urban Forestry \& Urban Greening, 9, 313-321.

[74]Zakri, A. H., Watson, R. (2003), Ecosystems and Human Well-being. A Framework for Assessment, Island Press, Washington, DC, US.

Article distributed under a Creative Commons AttributionNonCommercial-NoDerivatives 4.0 International License (CC BY-NC-ND). Received February 23, 2015

Accepted March 24, 2015

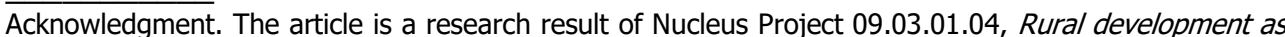
territorial competitiveness factor of reducing intra-regional disparities, phase 9 - Relations between ecosystem services and life strategies of rural communities within natural protected areas, funded by the Romanian National Agency for Scientific Research and Innovation. 